\title{
Supply chain quality management
}

\author{
Hannan Amoozad Mahdiraji*, Meysam Arabzadeh and Reza Ghaffari
}

\begin{tabular}{|c|c|}
\hline A R T I C L E I N F O & A B S T RACT \\
\hline $\begin{array}{l}\text { Article history: } \\
\text { Received April 25, } 2012 \\
\text { Accepted } 21 \text { July } 2012 \\
\text { Available online } \\
\text { July } 242012 \\
\text { Keywords: } \\
\text { Supply chain management } \\
\text { Total quality management } \\
\text { Performance improvement }\end{array}$ & $\begin{array}{l}\text { In recent years, there are several methods introduced for the improvement of operational } \\
\text { performances. Total quality management and supply chain management are two methods } \\
\text { recommended for this purpose. These two approaches have been studied in most researches } \\
\text { separately, while they have objectives in common, and this makes them a strategic means, } \\
\text { which can be used, simultaneously. Total quality management and supply chain management } \\
\text { play significant roles to increase the organizational competitiveness power. Moreover, they } \\
\text { have only one purpose that is customer satisfaction, and they are different only on their } \\
\text { approaches to reach their objectives. In this research, we aim to study both approaches of } \\
\text { quality management and supply chain, their positive increasing effects that may be generated } \\
\text { after their integration. For this purpose, the concept and definitions of each approach is studied, } \\
\text { independently, their similarities and differences are recognized, and finally, the advantages of } \\
\text { their integration are introduced. }\end{array}$ \\
\hline
\end{tabular}

\section{Introduction}

Nowadays, many companies adopted supply chain approaches as their business strategy to face the increasing pressure of customer-orientation and the growing trend of industrial globalization. This approach created new challenges for the quality management, in such a way that the term "my quality" has been substituted by a new term called "our quality". Although considerable attentions have been paid to the concept of supply chain management, poor attention is paid to its interaction with the approach of quality management, in form of secondary issues, which require addressing. Although the importance of total quality management has been accepted universally, its vastness and importance require conducting concentrated researches in the fields of supply chain and quality management to evaluate of the issues on quality management in relation to domestic or foreign supply chain of an organization.

* Corresponding author

E-mail addresses: Azad.Kashan@yahoo.com (H. Amoozad Mahdiraji) 
In the past decades, companies were not only required to improve uninterruptedly their quality and meet the needs of their costumers, but also they had to focus on the rapid and efficient competition in the changing world markets. Therefore, the philosophy known as supply chain management has been introduced, meaning an intra-organizational cooperation among companies and merger of strategic measures as well as upstream and downstream processes to achieve their peak in business. One of the most important outcomes used in common with other issues, is customer satisfaction from the quality of goods or services, and this satisfaction is regarded as a value for the organization. Therefore, it is required to improve quality not only inside the organization but also outside the organization and upstream and downstream supply chains and channels (Benaisa et al., 2010).

Considering the increase in the competitions of the world market and technological progresses throughout the world, quality managers and supply chain managers face new challenges, especially as the traditional method of quality management and supply change management are seemed terribly inefficient. However, the addition of the word "total" to the issues and principles of quality management has overcome internal and external challenges of organizational operations, and the total quality management approach has been introduced.

On the other hand, supply chain management has been selected as a method for the improvement of competitive performance by merging internal operations and processes, as well as linking them with the external suppliers and customers (Tutuncu, 2008). This may lead to the change in traditional structure of organizations. Therefore, the integration of total quality management is required to expand the perspective of supply chain management beyond its traditional viewpoint to costs and competitive relation and focus on the relation among the members of supply chain.

\section{Theoretical Framework of the Research}

As the title and objective of this research shows, first, the literature of this research is studied and then two fields of quality and supply chain managements are described as the theoretical framework of the research.

\subsection{Review of Literature}

Many researches on total quality management and supply chain management have been conducted; but, they mostly studied two separate fields and few studies have been carried out to research their integration and combinational models. Tutuncu (2008) studied the role and effect of the integration of quality management and supply chain of hospital equipments. The results of his research showed a positive relation and positive effects arising out of the combination of two approaches for health and medical care organizations.

Forker (1997) studied also the relation between two approaches of total quality management and supply chain management. The results and outcomes of his study showed positive effects of quality management on the improvement of the different level of supply chain. Wong (1999) studied the integration of supply chain management and quality management in construction projects. In their research, the construction projects in Hong Kong were studied, and as a result, several indices of supply chain were determined in the construction projects and the positive effects of quality management on the successful management of supply chain were recognized.

Flynn (2005) studied the supply chain improved by quality management approach. For this purpose, four hypotheses were recommended, evaluated, and tested, and finally, it was approved that there was a significant relation between these two approaches. Romano (2001) conducted a similar study in the 
field of textile industry, and the effect of quality on supply chain management has been studied to determine the positive or negative effects of such approach on the performance of supply chain.

In 2009 , a study has been conducted by Wanichinchai to study comprehensively the total quality management and supply chain management to show the differences and common issues of these two approaches. Sila (2006) studied the manufacturing industries of the United States of America to determined the satisfaction of the organizations of suppliers and different components of supply chain. The results of this research showed the mutual and positive effects of total quality management and supply chain management on the increase in power and compatibility of active organizations in chain supply as well as the improvement of the quality of manufactured products accompanied by the satisfaction of customers.

Bandipadi (2003) studied the effects of total quality management on the successful supply chain of automotive parts in USA. They concluded that the addition of total quality management to the supply chain as one of its components can result in suitable effects on the total performance of supply chain. Kuei (2002) studied in a research the variables affecting the quality of supply chain and found that the recognized variables that were in the group of quality variables impacted on the performance of supply chain. The reliability, continuity, and successful performance of a supply chain are independent from demand and uncertainty, rather they depends decisively on the quality of a supply chain. Kuei et al. (2008) carried out a study using statistical method and found the same results. In a research conducted by Ramous et al. (2007), four famous factories of different industries were studied using two statistical quality control instruments, and failure analysis, and the results were used in two instruments in supply chains of the factories. Lin et al. (2005) recognized the indices affecting the quality management of supply chain. Table 1 compares the previous researches in the field of quality management of supply chain.

\section{Table 1}

Previous Researches in the Field of Supply Chain Quality Management

\begin{tabular}{|c|c|c|c|}
\hline Item & Author & Year & Focus/Field of Study \\
\hline 1 & Tutuncu & 2008 & $\begin{array}{l}\text { The role and effect of the integration of quality management in the supply chain of } \\
\text { hospital equipments }\end{array}$ \\
\hline 2 & Forker & 1997 & $\begin{array}{l}\text { The relation between two approaches including total quality management and supply } \\
\text { chain management }\end{array}$ \\
\hline 3 & Wong & 1999 & $\begin{array}{l}\text { The integration of supply chain management and quality management in construction } \\
\text { projects }\end{array}$ \\
\hline 4 & Flynn & 2005 & The improvability of supply chain management using quality management \\
\hline 5 & Romanu & 2001 & The effects of quality on the supply chain management of textile industry \\
\hline 6 & $\begin{array}{l}\text { Wanichin } \\
\text { chai }\end{array}$ & 2009 & The differences and similarities of quality management and supply chain management \\
\hline 7 & Sila & 2006 & $\begin{array}{l}\text { The mutual and positive effects of total quality management and supply chain } \\
\text { management in automotive industry }\end{array}$ \\
\hline 8 & Bandipai & 2003 & $\begin{array}{l}\text { The effects of total quality management on the successful management of supply chain in } \\
\text { auto parts industry. }\end{array}$ \\
\hline 9 & Kuei & 2002 & The variables affecting the quality of supply chain \\
\hline 10 & Kuei & 2008 & The decisive role of quality in the performance of a supply chain \\
\hline 11 & Ramous & 2007 & $\begin{array}{l}\text { The effects of statistical quality control and failure analysis on the performance of supply } \\
\text { chain }\end{array}$ \\
\hline 12 & Lin et al. & 2005 & The indices effective in supply chain quality \\
\hline
\end{tabular}

\section{Supply Chain}

Supply chain includes all sections interconnected directly or indirectly to meet the needs of customers. These sections may include producer, supplier, carriers, warehouses, retailers, and customers. These sections are engaged in new product development, marketing, executive operations, 
distribution, financial services, customer services, etc. Supply chain is a dynamic set of information flow, product, and capital in different levels, in which customer is only an engaged and internal part of this chain. According to these definitions, the main objective of supply chain is to meet the needs of customers to their full satisfaction and create profit for the supply chain. Fig. 1 shows a given supply chain.

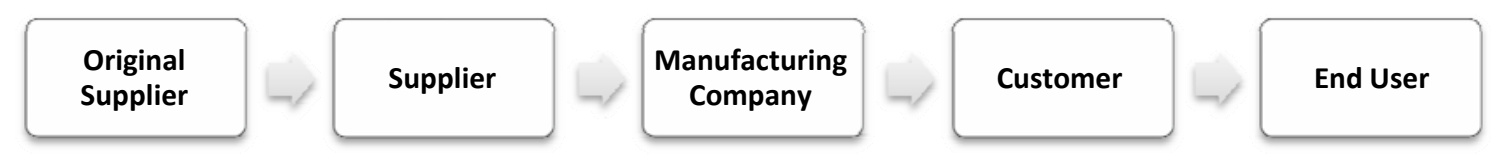

Fig. 1. A Given Supply Chain

As supply chains work mostly in network manner, it is better to use supply network for defining the structure of supply chain (Chopra \& Meindl, 2001). To draw an appropriate image of supply chain, attention must be paid to the needs of customers and the role of each section or level play in the whole chain considering the type of product, market, etc. (Mentzer, 2001). Fig. 2 shows the issues related to the supply chain management.

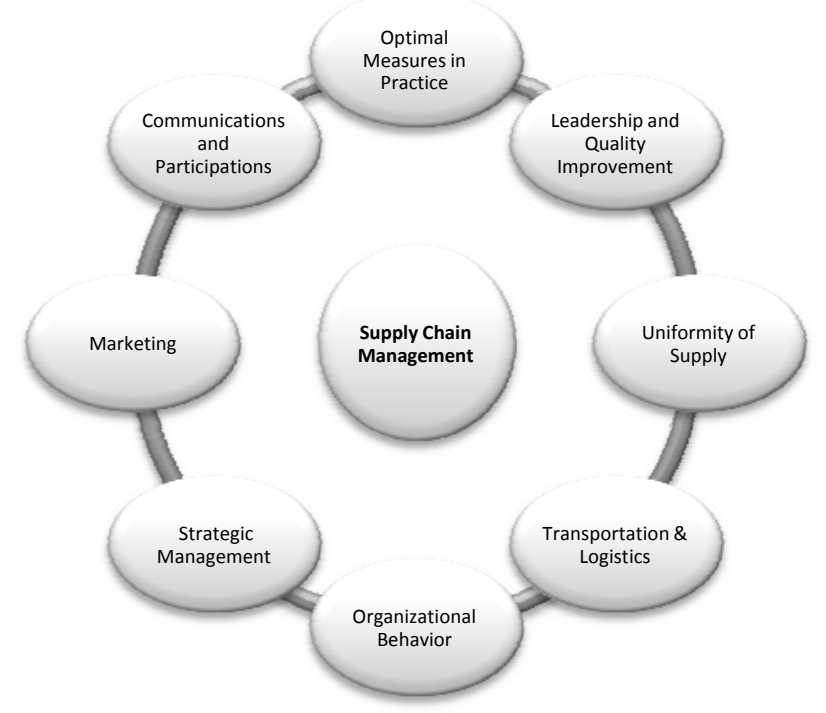

Fig. 2. The Issues Related to the Supply Chain Management

\section{Quality Management}

Quality management although has its root in the ancient times, its new definition as a modern issue in the field of goods and service has been introduced in the twentieth century. According to one approach, quality management means the supervision of the process of manufacture and production of products to ensure that the product conforms to what the designer or customer intended. This supervision begins from placing order for raw materials and their delivery up to the phase of aftersales service. Therefore, it covers a vast continuum of activities. Fig. 3 shows quality management perspectives. 


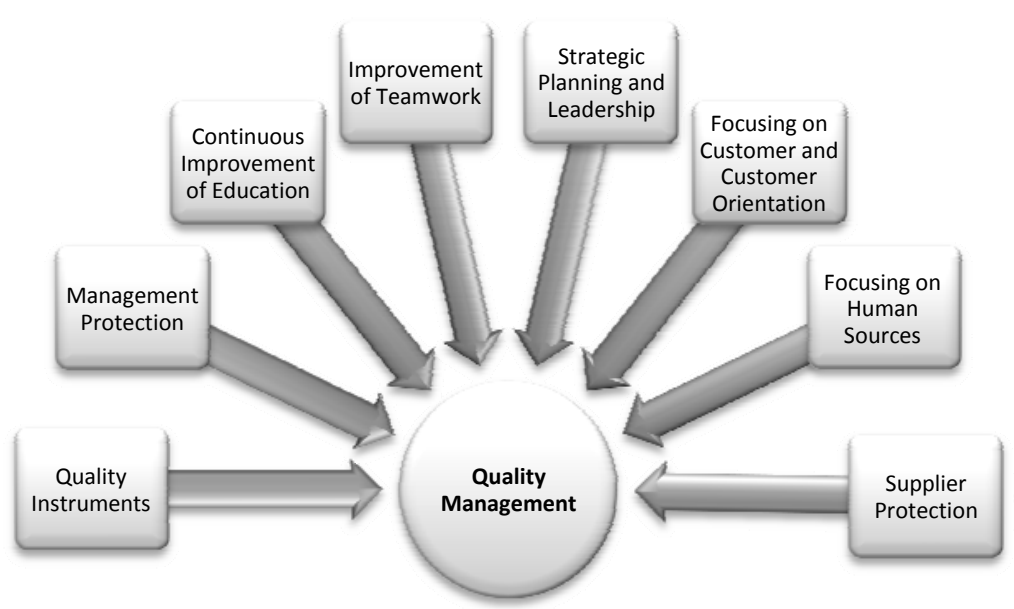

Fig. 3. Issues Relating to the Quality Management

Hermann (2005) identified the activities relating to quality management and classified them in five groups. The outcome of his research can be seen in Table 2 (Gunessekaran, 2004).

\section{Table 2}

Quality perspectives

\begin{tabular}{|c|c|c|}
\hline Item & Field & Activity \\
\hline 1 & \multirow{3}{*}{ Quality Policymaking } & Determine and declare quality policies \\
\hline 2 & & Determine the responsibilities of quality section \\
\hline 3 & & Determine the costs of quality \\
\hline 4 & \multirow{3}{*}{ Quality Planning } & Determine the indices for quality assessment \\
\hline 5 & & Determine the inspection and testing plans \\
\hline 6 & & Determine the quality management plans \\
\hline 7 & \multirow{7}{*}{ Quality Control } & Determine quality control methods \\
\hline 8 & & Determine and execute quality plans \\
\hline 9 & & Prepare quality reports \\
\hline 10 & & Determine quality evaluation and inspection methods \\
\hline 11 & & Control of inspection equipments \\
\hline 12 & & Inspection \\
\hline 13 & & Control and inspection of products and outputs \\
\hline 14 & \multirow{3}{*}{ Quality Assurance } & Organizing, keeping, and publishing the results of processes \\
\hline 15 & & Organizing, keeping, and publishing the results of products \\
\hline 16 & & Prepare, keep, and develop quality manual \\
\hline 17 & \multirow{2}{*}{ Quality Improvement } & Planning for improvement plans \\
\hline 18 & & Revision and evaluation of improvements \\
\hline
\end{tabular}

\section{Supply chain quality management}

Total quality management and supply chain management play a very effective role to increase in organizational power and competitiveness (Sila, 2006), and they both act for meeting one main objective, which is customer satisfaction. They only differ in terms of their approach and models used to meet this purpose. For example, total quality management focuses on quality, and supply chain management on the delivery as the basis for the cost price of products. However, it must be noted that higher quality and more appropriate deliver will lead to customer satisfaction and improves competitive power of the organization (Gunasekaran \& Ngai, 2004; Milles, 2004; Lamy 1996; Kannan \& Tan, 2005; Wanichichai 2009). In general, it can be claimed that total quality management emphasizes mostly on quality, while supply chain management on the provision of on-time services. Total quality management focuses mainly on internal participation, and supply chain management on external participation. Fig. 4 shows the differences of these two approaches of quality management and supply chain management in achieving the common objective (Kannan \& Tan, 2005). 


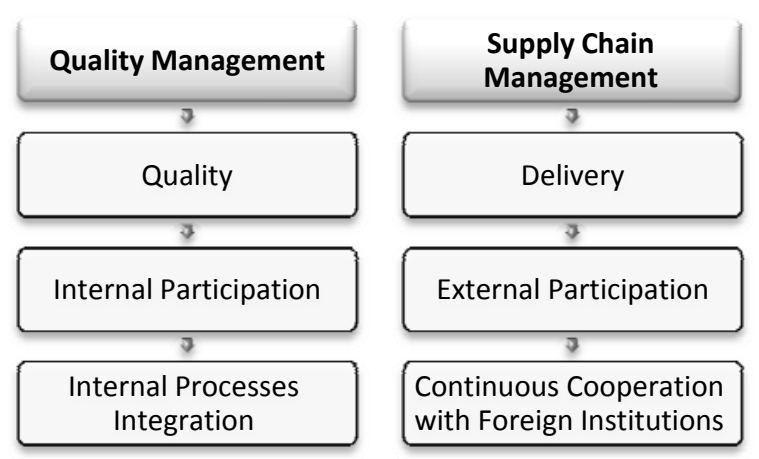

Fig. 4. Differences between quality management and supply chain management

\section{The definition of supply chain quality management}

To provide a definition of supply chain quality management, two terms - quality management and supply chain management - must be defined:

Supply chain quality management is an approach based on systemic idea to improve the performance of a set of organizations active in a supply chain. This approach uses upstream (towards suppliers) and downstream (towards customers) flows to penetrate into supply chain, and its reproduction in the supply chain improves the performance of all levels and components of supply chain network. Supply chain quality management is official coordination, integration of business processes, of all organizations that are members of a supply network for measurement, analysis, and continuous improvement of products, services, and processes to create value and achieve the satisfaction of all middle and end users of markets (Benaisa, 2010). Companies and organizations active in a special field depend largely on the effectiveness of supply chain. This leads to better and low-priced products, shorter time for accountability, and higher service-providing levels. For this purpose, supply chain network is defined as a set of networks of interconnected organizations that are ready to meet rapidly the needs and expectations of customers.

The terms including supply chain management, on-time production, total quality management, six Sigma, material planning, as well as supply chain quality management are the concepts extracted from supply chain networks in order to create an effective supply chain (Chue, 2006; Robinson, 2005; Kannan \& Tan, 2005; Takahashi, 2005; Madu \& Kuei, 2004; Tari, 2004; Kuei \& Madu, 2003; Muei, 2002; Muei and Madu 2001). Kuei and Madu (2001) provided an appropriate definition for supply chain quality management, in which the words of the whole term are defined in form of the parts of an equation, in order to define the total term supply chain quality management by their combination. This definition has been provided in the Table 3.

\section{Table 3}

The Definition of Supply Chain Management in Equation Form

\begin{tabular}{ccl}
\hline Item & Parts & Definition \\
\hline $\mathbf{1}$ & SC & A production network up to the phase of distribution \\
$\mathbf{2}$ & $\mathrm{Q}$ & Appropriate meeting of market demand, rapid customer satisfaction \\
$\mathbf{3}$ & $\mathrm{M}$ & Providing conditions and increase in confidence for the improvement of supply chain quality \\
\hline
\end{tabular}

\subsection{The Comparison of Total Quality Management and Supply Chain Management}

Before studying the similarities and interfaces between two approaches of total quality management and supply chain management, it is required to provide the definitions in different aspects. These definitions can help us recognize the indices required for the identification of the differences of these two approaches. Thereafter, the definitions of total quality management and supply chain 
management provided by a great scholar are studied. These definitions are based on the changes incurred in the course of time. These definitions are used to identify the similarities of these two approaches in the world of management, and provide indices to classify the similarities that are listed in the following:

1) Definition of each approach

2) Origin and source of each approach

3) Their developmental levels and process

4) Objectives of each approach

5) Focus of each approach

6) The instrument of each approach
7) Principles, regulations and instructions of each approach

8) The effective scope of each approach

9) The merging view of each approach

10) The usage and applications of each approach (Talib, 2005).

These indices are used here to compare the two approaches of total quality management and supply chain management. This comparison has been shown in the Table 4.

\section{Table 4}

The comparison of quality management and supply chain management

\begin{tabular}{|c|c|c|c|}
\hline Item & Indices & $\begin{array}{c}\text { Total Quality Management } \\
\end{array}$ & Supply Chain Management \\
\hline 1 & Definition & $\begin{array}{l}\text { A managerial philosophy focusing on the integration } \\
\text { of all levels, and emphasizing organizational } \\
\text { activities, continuous improvement, quality of goods } \\
\text { and services, as well as customer satisfaction }\end{array}$ & $\begin{array}{l}\text { A managerial philosophy focusing on the integration } \\
\text { with extra-organizational members in the supply } \\
\text { chain, and emphasizing the needs of customers, on } \\
\text { time delivery of goods and services, as well as } \\
\text { customers' satisfaction }\end{array}$ \\
\hline 2 & Origin and source & Quality & Strategy and Logistics \\
\hline 3 & $\begin{array}{l}\text { Developmental } \\
\text { levels and process }\end{array}$ & $\begin{array}{l}\text { Quality } \\
\text { Inspection } \\
\text { Control circles } \\
\text { Quality assurance } \\
\text { Quality management } \\
\text { Total quality management }\end{array}$ & $\begin{array}{l}\text { Logistics } \\
\text { Supply chain management } \\
\text { Universal supply chain management }\end{array}$ \\
\hline 4 & Objectives & $\begin{array}{l}\text { Increase in organizational competitiveness } \\
\text { Increase in customer satisfaction }\end{array}$ & $\begin{array}{l}\text { Increase in organizational competitiveness } \\
\text { Increase in customer satisfaction }\end{array}$ \\
\hline 5 & $\begin{array}{l}\text { Focus and } \\
\text { Emphasis }\end{array}$ & Characteristic or quality of product & Lead time or delivery date \\
\hline 6 & Instruments & $\begin{array}{l}\text { Six Sigma } \\
\text { Taguchi Methods } \\
\text { Quality circles } \\
\text { Quality awards }\end{array}$ & $\begin{array}{l}\text { Rapid accountability } \\
\text { On time production } \\
\text { Effective and efficient accountability }\end{array}$ \\
\hline 7 & Effective factors & $\begin{array}{l}\text { Top management obligations } \\
\text { Customer-orientation } \\
\text { Training and education } \\
\text { Continuous improvement } \\
\text { Innovation } \\
\text { Suppliers management } \\
\text { Personnel participation }\end{array}$ & $\begin{array}{l}\text { Customer relation } \\
\text { Material management } \\
\text { Strategic participation of suppliers } \\
\text { Technology information and technology } \\
\text { Organizational culture } \\
\text { Close participation of suppliers }\end{array}$ \\
\hline 8 & $\begin{array}{l}\text { Scope of } \\
\text { Effectiveness }\end{array}$ & $\begin{array}{l}\text { Goods safety } \\
\text { Flexibility } \\
\text { High-quality products } \\
\text { Quality management issues } \\
\text { Excellency models } \\
\text { Processes improvement } \\
\text { Repair and maintenance issues }\end{array}$ & $\begin{array}{l}\text { Rapid reaction to market } \\
\text { Nimbleness } \\
\text { Rapid meeting customer needs } \\
\text { Minimizing costs } \\
\text { Marketing } \\
\text { Recovery } \\
\text { Purchase or manufacture } \\
\text { Product design } \\
\text { Support } \\
\text { Inventory control } \\
\text { Purchase } \\
\text { Management of communicating with customers }\end{array}$ \\
\hline 9 & $\begin{array}{l}\text { Integration } \\
\text { approach }\end{array}$ & $\begin{array}{l}\text { Intra-organizational participation and internal } \\
\text { integration }\end{array}$ & Extra-organizational participation and integration \\
\hline 10 & $\begin{array}{l}\text { Usage and } \\
\text { Applications }\end{array}$ & $\begin{array}{l}\text { Production and services } \\
\text { Middle and small-sized companies } \\
\text { Organizations with ISO } 9000\end{array}$ & $\begin{array}{l}\text { Production } \\
\text { Retailers } \\
\text { Process industries } \\
\text { Organizations with ISO } 9000\end{array}$ \\
\hline
\end{tabular}




\subsection{The Advantages of the Integration of Total Quality Management and Supply Chain Management}

Considering the various definitions provided for total quality management and supply chain management, as well as the comparison of these two approaches using the abovementioned ten criteria, the following advantages have been resulted using conceptual analysis of the definitions and comparisons:

\section{Table 5}

The advantages of the integration of these two approaches

\begin{tabular}{cll}
\hline Item & The Advantages of Total Quality Management & The Advantages of Supply Chain Management \\
\hline 1 & Decrease in Operating Costs & Increase in Sales \\
3 & Increase in Financial Performance & Exact Costing \\
4 & Improvement of Organizational Morales & Increase in intra-organizational coordination \\
5 & Increase in customer satisfaction & Increase in coordination with suppliers \\
6 & Increase in the participation of personnel & $\begin{array}{l}\text { Increase in coordination and cooperation with } \\
\text { customers }\end{array}$ \\
7 & Faster introduction of new products to market & Increase in meeting the needs of customers \\
8 & Establish long-term relations & Increase in the interactions in supply chain \\
9 & $\begin{array}{l}\text { Increase in the commitment of the personnel to } \\
\text { continuous organizational improvement }\end{array}$ & Decrease in risk and inventory \\
\hline
\end{tabular}

In case of the integration of the two approaches of quality management and supply chain management, the issues relating to the supply chain quality management will be changed in the form of the Table 5.

\section{Table 5}

The issues related to the quality management of supply chain

\begin{tabular}{|c|c|c|c|c|c|c|}
\hline Quality Methods & ? & \multirow{4}{*}{$\begin{array}{l}\text { Focusing on intra- } \\
\text { organizational } \\
\text { relations } \rightarrow\end{array}$} & \multirow{4}{*}{$\begin{array}{c}\text { Internal } \\
\text { Corporate } \\
\text { Supply Chain } \\
\rightarrow\end{array}$} & \multirow{4}{*}{$\begin{array}{c}\text { Quality } \\
\text { Management }\end{array}$} & \multirow[b]{4}{*}{ ? } & \multirow{8}{*}{$\begin{array}{c}\text { Supply } \\
\text { Chain } \\
\text { Quality } \\
\text { Management } \\
\text { Issues }\end{array}$} \\
\hline Quality Leadership & 国 & & & & & \\
\hline Strategy & ? & & & & & \\
\hline $\begin{array}{l}\text { Internal Integrated } \\
\text { Processes }\end{array}$ & ? & & & & & \\
\hline $\begin{array}{c}\text { Supply Chain } \\
\text { Quality Leadership }\end{array}$ & 回 & \multirow{4}{*}{$\begin{array}{l}\text { Focusing on extra- } \\
\text { organizational } \\
\text { relations } \rightarrow\end{array}$} & \multirow{4}{*}{$\begin{array}{c}\text { External } \\
\text { Corporate } \\
\text { Supply Chain } \\
\rightarrow\end{array}$} & \multirow{4}{*}{$\begin{array}{l}\text { Supply Chain } \\
\text { Management }\end{array}$} & & \\
\hline $\begin{array}{l}\text { Participation and } \\
\text { Communication }\end{array}$ & ? & & & & & \\
\hline $\begin{array}{l}\text { Control Methods of } \\
\text { Supply Chain }\end{array}$ & ? & & & & ? & \\
\hline $\begin{array}{c}\text { Internal Integrated } \\
\text { Processes }\end{array}$ & ? & & & & & \\
\hline
\end{tabular}




\subsection{Indices for the Study of Supply Chain Quality Management}

To study the performance of supply chain quality management, Lin et al (2005) provided 15 indices in four sections including quality management practices, supplier participation, supplier selection, and organizational performance. The outcome of their research can be observed in the Table 6 .

Table 6

Indices for the Study of Supply Chain Quality Management

\begin{tabular}{|c|c|c|}
\hline Item & Section & Variables \\
\hline 1 & \multirow{9}{*}{ Quality Management Practices } & Top Management Leadership \\
\hline 2 & & Training \\
\hline 3 & & Product/service design \\
\hline 4 & & Supplier quality management \\
\hline 5 & & Process management \\
\hline 6 & & Quality data reporting \\
\hline 7 & & Employee relations \\
\hline 8 & & Customer relations \\
\hline 9 & & Benchmarking learning \\
\hline 10 & \multirow{2}{*}{ Supplier Participation } & Supplier participation in product design \\
\hline 11 & & Supplier participation in Kaizen projects/workshops \\
\hline 12 & \multirow{2}{*}{ Supplier Selection } & Quality-oriented supplier selection \\
\hline 13 & & Cost-oriented supplier selection \\
\hline 14 & \multirow{2}{*}{ Organizational Performance } & Satisfaction level \\
\hline 15 & & Business results \\
\hline
\end{tabular}

\section{Conclusions}

There are several methods common in supply chain to improve the performance of the activities carried out in this chain. For this purpose, it is required to share information and use the participation of all levels of supply chain in an efficient and effective manner using quality management means. Quality management has been introduced by many researchers as an active instrument for all industrial sections. In other words, organizations have used quality methods to improve their processes.

For this purpose, solutions including work facilitation for personnel, systematic solution of the contingent problems incurred in organization, and documentation of information are used. The results of the case studies show that quality management methods used in different industries are effective and satisfactorily valuable in this regard. This is a proper beginning point for the use of these methods to improve the supply chain performance.

Quality system of supply chain is a series of the relations between customer and supplier to create quality chain. Any member of this chain plays the role of supplier for the upstream members and customer for the downstream ones. By the integrated interactions of the members, quality requirements, information, etc, are transferred through the chain. The infrastructure of this model consists of social, environment, organizational culture, business environment, organizations standards and technology. Moreover, the mechanism of the interaction of customer-supplier through contract is 
realized by relation and cooperation. In conclusion, the following requirements are introduced for the realization of the quality management of supply chain:

1) The participation of all management team in the issues of product quality by paying attention to the needs of the customers and let the personnel understand the importance of the produced parts.

2) The personnel must participate in and cooperate with the solution team, and visit the premises of the customers to understand their needs better.

3) Multi-task teams composing of managers shall be formed to solve the problems and improve the internal processes of the company and the members of the supply chain.

\section{References}

Benaissa, M., Benabdelhafid, A., \& Akkouri, Z. (2010) Quality management approach in supply chain logistics. Management Studies, 152-168.

Chopra, S., \& Meindl, P. (2001). Supply Chain Management. Prentice-Hall., Englewood Cliffs., NJ.

Gunasekaran, A., \& Ngai, E.W.T. (2004). Information systems in supply chain integration and management. European Journal of Operational Research, 159(2), 269-295.

Kannan, V.R., \& Tan, K.C. (2005). Just in time, total quality management, and supply chain management: understanding their linkages and impact on business performance. Omega, 33(2), 153-162.

Kuei. C. (2008). Supply chain quality management: A simulation study. Information and Management Science, 19, 131-151.

Lin, C., Chow, W.S., Madu, C.N., Kuei, C.H., \& Yu, P.P. (2005). A structural equation model of supply chain quality management and organizational performance. International Journal of Production Economics, 96(3), 355-365.

Talib, F., R. Z.(2010). Integrating total quality management and supply chain management: Similarities and benefits. Information Technology and Economic Development, 53-58.

Tutuncu., O., \& Kucukusta., D. (2008)., The role of supply chain management in quality management system for hospitals. International Journal of Management Perspective, 1(1), 31-39.

Yan, J., Sun, S. X., Wang, H, \& Hua, Z. (2010). Ontology of collaborative supply chain for quality management. Proceedings of International Conference on Supply Chain Management. 